\title{
COMMENT
}

\section{DEGREE OF EVIDENCE NECESSARY TO PROVE CRIMINAL CHARGE IN CIVII SUIT IN ILLINOIS}

\author{
HARRY G. FINS*
}

T HEE English rule is that if the commission of a crime is directly in issue in any civil proceeding, it must be proved beyond a reasonable doubt. ${ }^{x}$ The general American rule, on the other hand, is that where proof of crime is necessary in a civil case, it is enough to prove it by a preponderance of the evidence. ${ }^{2}$

The Illinois Supreme Court has chosen, for reasons which are by no means obvious, to follow the English instead of the general American rule. Unfortunately, however, the later Illinois cases have confused and confounded the subject so that by the year I 925 the decisions were in hopeless conflict. Some followed the English and some the American rule. Thus, we find the following cases in support of the English view: Crandall $v$. Dawson $^{3}$ (slander for charge of perjury); Darling v. Banks ${ }^{4}$ (slander for charge of perjury); Harbison v. Shook (slander for charge of perjury); McConnell v. Delaware Mutual Safety Insurance Co. ${ }^{6}$ (Suit to recover insurance money from one alleged to have caused the fire); Germania Fire Insurance Co. v. Klewer ${ }^{7}$ (Suit on fire insurance policy where defense was made that plaintiff burned the building); Cottam v. National Mutual Church Insurance $\mathrm{Co}^{8}{ }^{8}$ (Action against fire insurance company, defense be-

* Member of the Illinois Bar.

1 Thurtell v. Beaumont, I Bing. 339 (I823) (action on fire insurance policy, defense being arson); Chalmers v. Sharkell, 6 C. \& P. 475 ( 1834 ) (action of libel for charging forgery); Willmett v. Harner, 8 C. \& P. 695 (1839) (action of slander for charging bigamy).

2 Mead v. Husted, 52 Conn. 56 ( 1884 ); Atlanta Journal v. Mayson, 92 Ga. 640 (r893); Continental Ins. Co. v. Jacknichen, rro Ind. 59, ro N.E. 636 (r886); Turner v. Hardin, 80 Iowa 69r, 45 N.W. $75^{8}$ (1890); Roberge v. Burnham, 124 Mass. 277 (I878); Baird v. Abbey, 73 Mich. 347, 4I N.W. 272 (I889); Smith v. Burns, I06 Mo. 694, I6 S.W. 88I (I89I); Nelson v. Pierce, 18 R.I. 539, 28 Atl. 806 (1894); Lindley v. Lindley, 68 Vt. 42I, 35 Atl. 349 (I896); U. S. Express Co. v. Jenkins, 73 Wis. 47 I , 4 I N.W. 957 ( 1889 ).

3 Crandall v. Dawson, I Gilm. (IIl.) 556 (1844).

4 Darling v. Banks, I4 Ill. 46 (I852). 5 Harbison v. Shook, 4I Ill. I4I (I866).

${ }^{6} \mathrm{McC}$ Connell v. Delaware Mutual Safety Insurance Co., r8 Ill. 229 (I856).

7 Germania Fire Insurance Co. v. Klewer, 129 Ill. 599, 22 N.E. 489 (1889).

${ }^{8}$ Cottam v. National Mutual Church Insurance Co., 209 Ill. App. 404 (IgI8). 
ing that plaintiff had committed arson); Rudolph Stecher Brewing Co. v. $\mathrm{Carr}^{9}$ (Action on a check, plea being that check was given for the compounding of a felony, and was, therefore, void); Smith v. Lawley ${ }^{\mathrm{xo}}$ (malicious prosecution); People v. Sullivan ${ }^{\text {Ir }}$ (disbarment of attorney on ground of conspiracy); Sprague v. Dodge ${ }^{\mathrm{T2}}$ (strong dictum in an assumpsit, alleging that defendant burned the mill); Grimes v. Hilliary ${ }^{\mathrm{I3}}$ (strong dictum in suit on a note, declaration charging the destruction of the note by defendant); McInturff v. Insurance Co. of North America ${ }^{\mathrm{r} 4}$ (strong dictum in suit on a fire insurance policy where defense was made that plaintiff burned the property); Oliver v. Ross ${ }^{\mathrm{Is}}$ (very strong dictum in a suit to set aside deed on ground of forgery); Pley v. Lavette ${ }^{16}$ (very strong dictum in suit for assault and battery with a loaded pistol); Sutton v. Workmeister ${ }^{17}$ (dictum in suit for an unlawful confederation at common law); City of Chicago v. Stone ${ }^{18}$ (dictum in a prosecution to recover penalty for the violation of a city ordinance in keeping a place for the purpose of gambling). The following cases adhere to the English rule, but hold that it does not apply where the person accused of the crime is a third party-agent or otherwise-who is not a party to the suit: Foster v. Graf, ${ }^{19}$ Waggoner $v$. Clark, ${ }^{20}$ Bernier v. Ill. Central R.R. Co., ${ }^{2 x}$ Foster v. Liverpool \& London Globe Insurance Co. ${ }^{22}$ Wilson Grocery Co. v. National Surety Co., ${ }^{23}$ Sussman v. Mass. Bonding and Insurance Co. ${ }^{24}$

On the other hand, the following Illinois decisions support the general American view: Oliver $v$. Olivere (allegation of forgery); Roberts $v$.

9 Rudolph Stecher Brewing Co. v. Carr, I94 Ill. App. 32 (Igrs).

Io Smith v. Lawley, I49 Ill. App. 480 (Igog).

"People v. Sullivan, 218 Ill. 4I9, 75 N.E. I005 (Ig05).

${ }^{2}$ Sprague v. Dodge, 48 Ill. I $_{42}$ (I868).

${ }^{23}$ Grimes v. Hilliary, I50 Ill. I4I, 36 N.E. 977 (1894).

${ }_{4}$ MicInturff v. Insurance Company of North America, 248 Ill. 92, 93 N.E. 369 (rgIo).

is Oliver v. Ross, 289 Ill. 624 , I24 N.E. 800 (rgrg).

${ }^{16}$ Pley v. Lavette, I67 Ill. App. 494 (I9r2).

${ }_{17}$ Sutton v. Workmeister, I64 Ill. App. I05 (I9II).

${ }^{18}$ City of Chicago v. Stone, 187 Ill. App. 90 (IgI4).

19 Foster v. Graf, 287 IIl. 559, I 22 N.E. 845 (Igrg).

${ }^{20}$ Waggoner v. Clark, 293 Ill. 256, I27 N.E. 436 (x920).

2x Bernier v. Ill. Central R.R. Co., 296 Ill. 464, I29 N.E. 747 (I92x) affirming 215 Ill. App. 454 .

22 Foster v. Liverpool \& London Globe Ins. Co., 222 Ill. App. 37 (I92I).

${ }_{23}$ Wilson Grocerie Co. v. National Surety Co., $218 \mathrm{Mll}$. App. 584 (r920).

${ }^{24}$ Sussman v. Mass. Bonding \& Insurance Co., 230 Ill. App. 276 (1923).

25 Oliver v. Oliver, I Io IIl. IIg (I884). 
Woods ${ }^{26}$ (allegation of forgery); Christopherson v. Marhoefer ${ }^{27}$ (false pretense, deceit and fraud); Crane v. Schaefer ${ }^{28}$ (deceit); Solomon v. Buechle $e^{29}$ (assault and battery); Chestnut v. Chestnut ${ }^{30}$ (divorce on ground of adultery); Stiles v. Stiles ${ }^{3 x}$ (divorce on ground of adultery); Lenning v. Lenning $^{32}$ (divorce on ground of adultery); Heyman v. Heyman ${ }^{33}$ (divorce on ground of adultery).

In the case of Rost $v$. Noble \& $\mathrm{Co}^{34}$ an action was brought by an administrator to recover damages for the death of his intestate. The declaration alleged that the deceased, who was a boy between fifteen and sixteen years old, was employed by defendant in operating a drill machine, and in carrying, transferring, loading and unloading boxes filled with material of great weight and hoisting the same by the elevator; that this work was such extra hazardous employment that it was dangerous to the deceased's life or limb, and he was then and there unlawfully employed at said work, contrary to the statute of the state (a misdemeanor). The jury was instructed that plaintiff was not required to establish his case beyond a reasonable doubt, but only by a preponderance of the evidence. The record was brought before the Supreme Court for a review by a writ of certiorari and this instruction was insisted upon as error. The Court recognized the Illinois rule to be that where a crime is charged in the pleadings in civil actions, the rule of evidence in criminal cases is applicable and the crime charged must be proved beyond a reasonable doubt, but limited the boundaries of this rule by saying that it applies only to civil cases where the cause of action or defense is based on a felony, and as to other offenses a preponderance of the evidence is sufficient. This distinction was introduced into the Illinois cases for the first time. The ratio decidendi was given as follows: ${ }^{35}$

This rule, which has prevailed from very early in the history of the State, has been consistently adhered to and frequently announced, except in actions of slander or libel, in which it is provided by chapter $I 26$ of the Revised Statutes of 1874 that it shall be

${ }^{26}$ Roberts v. Woods, 82 Ill. App. 630 (1898).

- ${ }^{27}$ Christopherson v. Marhoefer, 233 Ill. App. 42 (I924).

${ }^{28}$ Crane v. Schaefer, r4o Ill. App. 647 (igo8).

${ }^{29}$ Solomon v. Buechle, $x 19$ Ill. App. 595 (1905).

${ }^{30}$ Chestnut v. Chestnut, 88 Ill. 548 (I878).

${ }^{3 x}$ Stiles v. Stiles, 167 Ill. 576,47 N.E. 867 (I897).

${ }^{32}$ Lenning v. Lenning, 76 Ill. $x 80,52$ N.E. 46 (1898).

33 210 Ill. 524, $7 x$ N.E. $59 \mathrm{I}$ (1904). The following cases of divorce on the ground of adultery support the same view: Carter vs. Carter, 62 IIl. 439 (1872); Jenkins v. Jenkins, 86 Ill. 340 (1877); and Balswic v. Balswic, 178 Ill. App. I18 (I912).

${ }^{34}$ Rost v. Noble \& Co., 316 Ill. 357, 147 N.E. 258 (opinion filed February r7, 1925). 35 At p. 37 r. 
competent for the defendant to establish the truth of the matter charged by a preponderance of the testimony. [Citing Illinois cases.] The rule had its origin in England, where there was a reason for its existence arising from the fact that there, 'where a defendant justifies words which amount to a charge of felony and proves his justification the plaintiff may be put on his trial by that verdict without the intervention of a grand

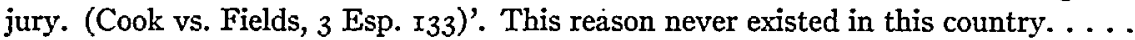
The reason in which the rule seems to have had its origin is applicable only to cases where the charge was only a felony, and in general it is in such cases, only, that the rule has been applied. It will not be extended further but is limited to charges of felony. The offenses for which penalties are imposed by the statute [misdemeanors] are not crimes of a character the charge of which in a civil suit is required to be proved beyond a reasonable doubt, and the instruction properly so advised the jury.

Since 1925 , four reported cases have dealt with the question under consideration. All of these have followed the opinion in Rost v. Noble and Co $^{36}$ They are: People v. Small ${ }^{37}$ (dictum); Gannon v. Kiel ${ }^{38}$ (automobile collision); Cooper v. Nutt ${ }^{39}$ (action by a stockholder against corporation to collect a penalty); and Kuhl v. Clark ${ }^{40}$ (alleging conspiracy to defraud complainant).

What is the Illinois law now? (I). The rule of "evidence beyond a reasonable doubt" does not apply to slander and libel cases, because an Illinois statute specifically provides that a preponderance of the evidence is sufficient. ${ }^{4 x}(2)$. The rule does not apply to misdemeanors, because the case of Rost $v$. Noble E $\mathrm{Co}$. has limited it to felonies. (3). The rule does not apply where the person accused of the crime is a third party-agent or otherwise-who is not a party to the suit, because Foster v. Graff and other cases cited above so hold. Thus, we are again left with a complicated situation. Would it not be much more advisable to accept the general American rule that a preponderance of the evidence is sufficient in all civil cases? We hope that the next time this question is brought before our Supreme Court, this august body will reconsider the subject and definitely follow the American instead of the English decisions. Such a step will be justified in view of the confusion and complication of Tllinois cases, and particularly in view of the fact that the English rule had a basis for its existence in England, but never had a reason for its continuance in this country. Rost v. Noble $\mathcal{F}^{\circ} \mathrm{Co}^{42}$ specifically so states. With this in mind,

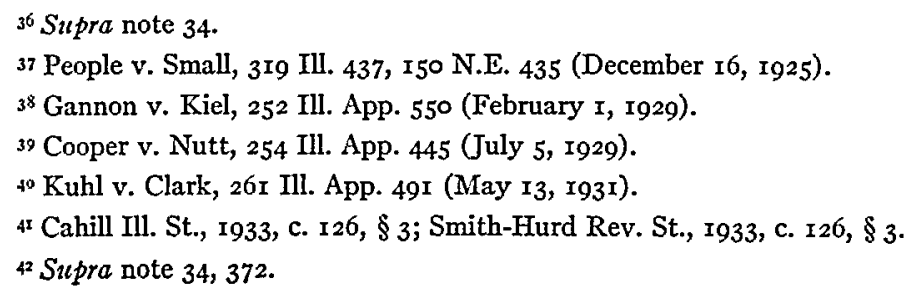


we should apply the well established principle of law that when the reason for a rule ceases to exist, the rule must cease with it. Some of the jurisdictions which formerly adhered to the English doctrine have abandoned it, apparently on this ground.43

We believe that it is rather safe to predict that Mllinois too will discard the English rule. This is evident from the hint which was dropped by our Supreme Court in the case of People v. Small, ${ }^{44}$ opinion filed December 16 , I925, only ten months after the Rosi case. At page $48 \mathrm{I}$, the majority opinion of five to two reads:

It is finally contended that criminal acts are charged in the bill in this suit, and that the rule that such charges must be proven beyond a reasonable doubt before a decree can be entered against the party so charged is applicable. We shall not lengthen this opinion by discussing this question. Whether this court will again apply to civil actions the rule of evidence applicable to criminal cases merely because the pleadings charge and the proof shows that the loss or damages arose out of a criminal act (see Rost $v$. Noble \& Co. 3 I 6 Ill. 357) need not be decided in this case, for the reason that whatever rule is applied, the evidence in this record shows, beyond all reasonable doubt, a liability to account. Proof of the fact that a public official having custody of public funds loaned these funds to others with a secret arrangement respecting the payment of interest and that in reporting interest collected he did not reveal the source of the payments, without more, would be sufficient to justify an order to account.

This hint, we hope, is a preface to a future decision ushering in the general American view in Illinois.

43 Gordon v. Parmalee, $\mathrm{I}_{5}$ Gray (Mass.) 4I3 (r860); Ellis v. Buzzell, 60 Mo. 209 (r872); Matthews v. Huntley, 9 N.H. I46 ( 1838 ); Jones v. Greaves, 26 Ohio St. 2 (1874); Weston v. Granelin, 49 Vt. 507 ( 1877 ); Washington Ins. Co. v. Wilson, 7 Wis. I69 (1858). See Rost v. Noble \& Co., supra note 34,372 .

${ }^{44}$ Supra note 37. 